УДК 616-097-02:616.523-06]:612.017.1

М.О. Соколенко, В.Д. Москалюк, А.А. Соколенко

\title{
ВПЛИВ ГЕРПЕСВІРУСІВ НА ІМУННИЙ СТАТУС ПАЦІНТІВ, НЕІНФІКОВАНИХ ВІЛ-ІНФЕКЦІЄЮ
}

Вищий державний навчальний заклад України «Буковинський державний медичний університет», м. Чернівці

Резюме. При аналізі імунограм 59 хворих на різні клінічні форми герпетичної інфекції встановили тенденцію до зниження більшості показників клітинного імунітету. Тільки при генітальному, оперізувальному герпесі та інфекційному мононуклеозі число $\mathrm{TCD}^{+}-$, $\mathrm{TCD} 4^{+}$-лімфоцитів достовірно знижувалося, а імунорегуляторний індекс зазнавав статистично вагомого зниження тільки при інфекційному мононуклеозі.

Вступ. Герпесвіруси постійно персистують в організмі більшості людей (90 \%) і є пантропними, у зв'язку з чим відомий широкий клінічний поліморфізм перебігу герпесвірусних інфекцій (ГВІ) у людини з ураженням багатьох органів i систем. Герпесвіруси тривалий період перебувають у клітинах імунної і нервової систем $[1,2]$.

Вірусами простого герпесу інфіковано 65-90 \% дорослого і дитячого населення планети. В Європі різними формами ГВІ щорічно інфікується близько 20 млн людей. Аналіз щорічної захворюваності на ГВІ у м. Санкт-Петербург показує, що в 15 \% населення розвивається герпетичне ураження шкіри і слизових оболонок, генітальний герпес і захворювання нервової системи, зумовлені герпесвірусами. У $6-10 \%$ дорослих людей реєструється захворювання нервової системи, зумовлені герпесвірусами. У 14-30 \% випадків тривало зберігаються залишкові явища (аж до інвалідизації) 3 летальністю від 5 до 70 \% залежно від клінічної картини ураження центральної нервової системи $[1,3]$.

Вищевикладене дозволяє вважати ГВІ важливою медико-соціальною проблемою сучасної охорони здоров'я та обгрунтовує необхідність іiі вивчення в сучасних умовах.

Мета дослідження. 3'ясувати вплив різних типів герпесвірусів на імунний статус пацієнтів, неінфікованих ВІЛ-інфекцією.

Матеріал і методи. Обстежили 59 хворих на різні клінічні форми герпетичної інфекції: 11 на лабіальний герпес та/або афтозний стоматит, 10 - на генітальний герпес, 21 - на оперізувальний герпес і 17 - на інфекційний мононуклеоз. Серед зазначених пацієнтів було 32 (54,2 \%) чоловіки і 27 (45,8 \%) жінок віком від 19 до 49років. Середній вік становив $32,4 \pm 0,9$ року. Розширений спектр імунологічних показників у хворих на герпесвірусну інфекцію вивчений методом проточної цитометрії.

Контрольну групу склали 30 практично здорових людей, цілком зіставних за віковою категорією та статевим складом.

Статистичну обробку отриманих результатів проводили за допомогою програмного комплексу
Концентрація сироваткових ІЛ-8, ІЛ-10, ІЛ-12, ІЛ17 та більшість показників гуморального імунітету не зазнавала суттєвих змін. Разом з тим, відзначили підвищення рівня IgA при лабіальному герпесі та/або афтозному стоматиті, а також при генітальному герпесі.

Ключові слова: герпетична інфекція, клітинний та гуморальний імунітет, цитокіновий статус.

STATISTICA 6.0 з використанням методу варіаційної статистики з визначенням достовірності за допомогою непараметричного методу Вілкоксона для незалежних сукупностей. Для порівняння двох незалежних груп використовували $U$ критерій Манна-Уїтні. Розбіжності вважали статистично значущими при $\mathrm{P}<0,05$ [4].

Результати досліджень та їх обговорення. При аналізі показників імунограми (табл. 1) у хворих на досліджувані клінічні форми герпетичної інфекції встановили, що абсолютна кількість лейкоцитів і лімфоцитів демонструвала тенденцію до зниження (Р>0,05). При інфекційному мононуклеозі спостерігали таку ж тенденцію стосовно абсоютної кількості лімфоцитів (Р>0,05). Тільки у хворих на лабіальний герпес та/або афтозний стоматит рівень абсолютної кількості лейкоцитів і лімфоцитів залишався практично незмінним.

Абсолютна кількість TCD3 ${ }^{+}$-лімфоцитів статистично достовірно знижувалася при геніталь-

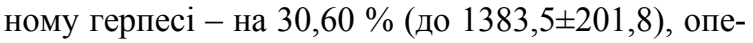
різувальному герпесі - на 38,82 \% (до 121$9,6 \pm 114,1)$ та інфекційному мононуклеозі - на $34,28 \%$ (до $1310,2 \pm 155,6$ ) клітин/мкл.

Вміст $\mathrm{TCD}^{+}-$-клітин демонстрував таке ж зниження тільки при генітальному герпесі - на $45,82 \%$ (до 1080,2 $\pm 48,7)(\mathrm{P}<0,05)$ та інфекційному мононуклеозі - на 65,87 \% (до 680,4 $\pm 82,1$ ) клітин/мкл $(\mathrm{P}<0,02)$. Рівень $\mathrm{TCD} 8^{+}$-лімфоцитів залишався практично незмінним.

Абсолютна кількість NK $\left(\mathrm{TCD}_{16}^{+}\right.$лімфоцитів), що виконують кілерну функцію, демонструвала тільки тенденцію до зниження на 3,61-35,17 \% при усіх клінічних формах герпетичної інфекції $(\mathrm{P}>0,05)$.

При такій динаміці $\mathrm{TCD} 4^{+}-$i $\mathrm{TCD} 8^{+}$-клітин імунорегуляторний індекс (CD4/CD8) зазнавав статистично вагомого зниження тільки при інфекційному мононуклеозі - на 43,02 \% (до $1,51 \pm 0,20)$ порівняно 3 показником у практично здорових осіб $(\mathrm{P}<0,05)$.

При аналізі показників $\mathrm{TCD}^{+}-, \mathrm{TCD}^{+}-$ кластерних клітин (рис. 1) і їх співвідношення при герпетичних інфекціях (рис. 2) виявили, що в 
Таблиця 1

Показники клітинного імунітету хворих на різні клінічні форми герпесвірусної інфекції (M \pm m)

\begin{tabular}{|c|c|c|c|c|c|}
\hline \multirow[b]{2}{*}{ Показник } & \multicolumn{4}{|c|}{ Хворі на герпесвірусну інфекцію (n=59) } & \multirow[b]{2}{*}{$\begin{array}{c}\text { Здорові особи } \\
(\mathrm{n}=30)\end{array}$} \\
\hline & \begin{tabular}{|c|} 
лабіальний гер- \\
пес та/або афтоз- \\
ний стоматит \\
$(\mathrm{n}=11)$ \\
\end{tabular} & $\begin{array}{c}\text { генітальний герпес } \\
(\mathrm{n}=10)\end{array}$ & $\begin{array}{c}\text { оперізувальний } \\
\text { герпес } \\
(\mathrm{n}=21)\end{array}$ & $\begin{array}{c}\text { інфекційний мо- } \\
\text { нонуклеоз } \\
(\mathrm{n}=17)\end{array}$ & \\
\hline Лейкоцити, Г/л & $6,28 \pm 0,84$ & $5,74 \pm 0,90$ & $5,25 \pm 0,51$ & $4,92 \pm 1,21$ & $6,73 \pm 0,62$ \\
\hline Лімфоцити, Г/л & $2,76 \pm 0,62$ & $2,36 \pm 0,96$ & $1,73 \pm 0,57$ & $4,18 \pm 1,09$ & $2,68 \pm 0,45$ \\
\hline CD3, клітин/мкл & $1778,6 \pm 210,7$ & $1383,5 \pm 201,8^{*}$ & $1219,6 \pm 114,1^{*}$ & $1310,2 \pm 155,6^{*}$ & $1993,6 \pm 188,9$ \\
\hline CD4, клітин/мкл & $1311,8 \pm 94,9$ & $1080,2 \pm 48,7^{*}$ & $839,3 \pm 70,3$ & $680,4 \pm 82,1^{* *}$ & $1422,5 \pm 95,7$ \\
\hline CD8, клітин/мкл & $517,2 \pm 92,2$ & $508,8 \pm 36,4$ & $460,0 \pm 62,2$ & $433,5 \pm 75,0$ & $537,8 \pm 60,2$ \\
\hline CD16, клітин/мкл & $341,5 \pm 78,9$ & $298,0 \pm 52,1$ & $262,3 \pm 59,1$ & $229,7 \pm 70,3$ & $354,3 \pm 51,0$ \\
\hline $\mathrm{CD} 4 / \mathrm{CD} 8$ & $2,52 \pm 0,34$ & $2,05 \pm 0,40$ & $1,79 \pm 0,39$ & $1,51 \pm 0,20^{*}$ & $2,65 \pm 0,27$ \\
\hline
\end{tabular}

Примітки (тут і далі). ${ }^{*}$ - достовірна різниця порівняно з показниками у здорових осіб за критерієм Манна-Уїтні $(\mathrm{P}<0,05) ;{ }^{* *}-\mathrm{P}<0,02$

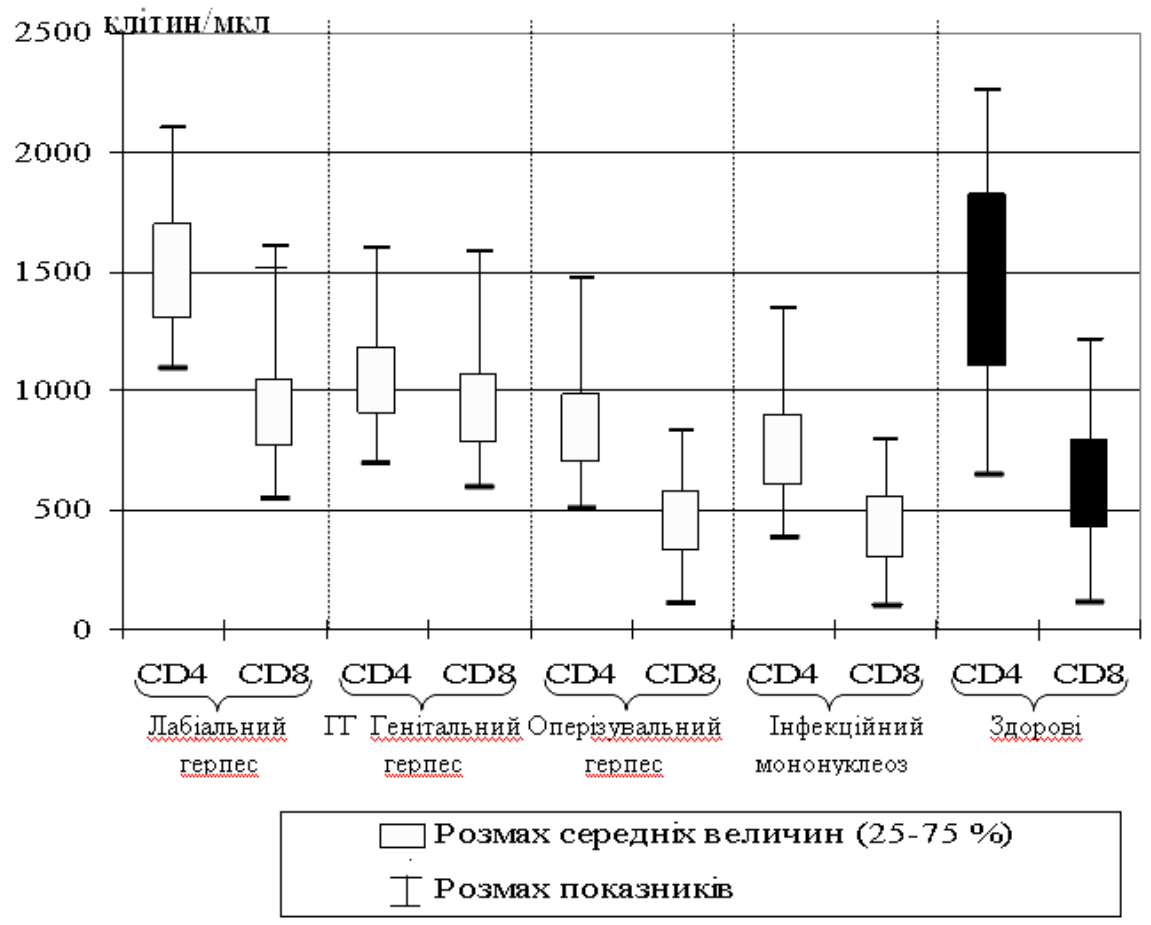

Рис. 1. Показники $\mathrm{CD}^{+}$- i CD8 ${ }^{+}$-кластерних клітин у хворих на герпетичну інфекцію

контрольній групі розподіл $\mathrm{TCD}^{+}-$і $\mathrm{TCD}^{+}-$ клітин приблизно відповідає співвідношенню 2,7:1. У хворих на усі аналізовані форми герпесвірусної інфекції кількість $\mathrm{TCD}^{+}-$і $\mathrm{CD} 8^{+}$-клітин дещо зменшується, але кількість TCD4 ${ }^{+}$-клітин у більшості пацієнтів залишається вищою, ніж вміст TCD $8^{+}$-клітин.

Зміни сироваткового рівня ІЛ-8, ІЛ-10, ІЛ-12 та ІЛ-17 у хворих на герпетичну інфекцію представлені в таблиці 2. Важливо, що значення ІЛ-8, ІЛ-10 та ІЛ-17 не зазнавали достовірних змін, хоча можна відзначити тенденцію до деякого зростання їх рівнів, передусім при оперізувальному герпесі та інфекційному мононуклеозі.

Не вирізнявся достовірною зміною й рівень ІЛ-12. Однак при інфекційному мононуклеозі та, меншою мірою, при генітальному герпесі встановили найнижче значення цього показника - відповідно $(4,31 \pm 1,21)$ і $(5,51 \pm 2,10)$ при нормі $(7,85 \pm 2,13)$ пг/мл $(\mathrm{P}>0,05)$. Вважаємо, що низький рівень ІЛ-12 може бути зумовлений нездатністю збудника індукувати синтез цього цитокіну або, навпаки, - селективною інгібіцією синтезу останнього, що дозволяє збудникам тривало персистувати в організмі хворого.

Більшість показників гуморального імунітету (табл. 3) також не зазнавала суттєвих змін. Разом з тим, варто відзначити підвищення у 2,24 раза рівня IgA при лабіальному герпесі та/або афтозному стоматиті (до $3,12 \pm 0,71$ ), а також при генітальному герпесі у 2,32 раза (до $3,22 \pm 0,84$ ) г/ л, що перевищує значення здорових осіб $(1,39 \pm 0,26)$ г/л $(\mathrm{P}<0,05)$, що засвідчує переважан- 
Таблиця 2

Вміст окремих інтерлейкінів у хворих на різні клінічні форми герпетичної інфекції (M \pm m)

\begin{tabular}{|c|c|c|c|c|c|}
\hline \multirow[b]{2}{*}{ Показник } & \multicolumn{4}{|c|}{ Хворі на герпесвірусну інфекцію (n=59) } & \multirow[b]{2}{*}{$\begin{array}{l}\text { Здорові особи } \\
\text { (n=30) }\end{array}$} \\
\hline & $\begin{array}{c}\text { лабіальний герпес } \\
\text { та/або афтозний } \\
\text { стоматит } \\
(\mathrm{n}=11) \\
\end{array}$ & $\begin{array}{c}\text { генітальний гер- } \\
\text { пес } \\
(\mathrm{n}=10)\end{array}$ & $\begin{array}{c}\text { оперізувальний } \\
\text { герпес } \\
(\mathrm{n}=21)\end{array}$ & $\begin{array}{c}\text { інфекційний } \\
\text { мононуклеоз } \\
(n=17)\end{array}$ & \\
\hline ІЛ-8, пг/мл & $16,28 \pm 9,63$ & $20,01 \pm 10,43$ & $25,15 \pm 9,90$ & $28,22 \pm 10,11$ & $14,38 \pm 5,66$ \\
\hline ІЛ-10, пг/мл & $0,152 \pm 0,085$ & $0,170 \pm 0,092$ & $0,161 \pm 0,047$ & $0,234 \pm 0,050$ & $0,118 \pm 0,033$ \\
\hline ІЛ-12, пг/мЛ & $5,88 \pm 1,84$ & $5,51 \pm 2,10$ & $6,09 \pm 1,44$ & $4,31 \pm 1,21$ & $7,85 \pm 2,13$ \\
\hline ІЛ-17, пг/мЛ & $0,533 \pm 0,242$ & $0,623 \pm 0,299$ & $0,570 \pm 0,153$ & $0,810 \pm 0,232$ & $0,534 \pm 0,141$ \\
\hline
\end{tabular}

Таблиця 3

Показники гуморального імунітету хворих на різні клінічні форми герпесвірусної інфекції (M \pm m)

\begin{tabular}{|c|c|c|c|c|c|}
\hline \multirow[b]{2}{*}{ Показник } & \multicolumn{4}{|c|}{ Хворі на герпесвірусну інфекцію (n=59) } & \multirow[b]{2}{*}{$\begin{array}{c}\text { Здорові особи } \\
(n=30)\end{array}$} \\
\hline & $\begin{array}{c}\text { лабіальний гер- } \\
\text { пес та/або аф- } \\
\text { тозний стоматит } \\
(\mathrm{n}=11)\end{array}$ & $\begin{array}{c}\text { генітальний гер- } \\
\text { пес } \\
(\mathrm{n}=10)\end{array}$ & $\begin{array}{c}\text { оперізувальний } \\
\text { герпес } \\
(\mathrm{n}=21)\end{array}$ & $\begin{array}{c}\text { інфекційний мо- } \\
\text { нонуклеоз } \\
(n=17)\end{array}$ & \\
\hline $\operatorname{IgM,~г/л~}$ & $1,49 \pm 0,34$ & $2,02 \pm 0,52$ & $1,23 \pm 0,31$ & $1,80 \pm 0,48$ & $1,88 \pm 0,31$ \\
\hline $\mathrm{IgG}$, г/л & $7,45 \pm 1,98$ & $6,14 \pm 2,10$ & $8,15 \pm 1,40$ & $8,22 \pm 2,37$ & $6,54 \pm 1,60$ \\
\hline $\operatorname{IgA,~Г/л~}$ & $3,12 \pm 0,71^{*}$ & $3,22 \pm 0,84^{*}$ & $2,30 \pm 0,72$ & $1,84 \pm 0,55$ & $1,39 \pm 0,26$ \\
\hline ЦІК, опт. од. & $53,1 \pm 14,9$ & $46,3 \pm 15,8$ & $70,9 \pm 10,6$ & $74,2 \pm 11,9$ & $52,7 \pm 8,5$ \\
\hline
\end{tabular}

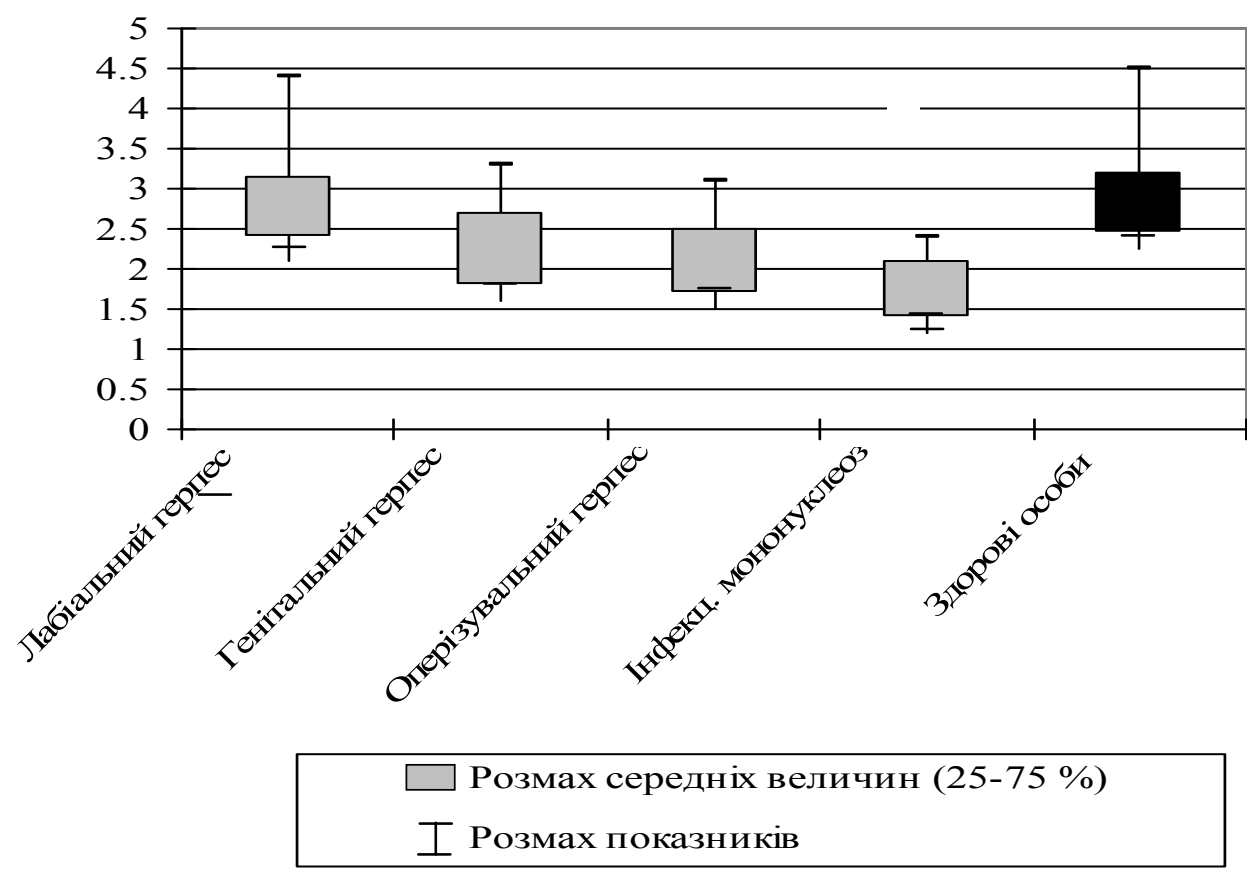

Рис. 2. Показники імунорегуляторного індексу у хворих на герпетичну інфекцію

ня запального процесу на слизових оболонках. При оперізувальному герпесі та інфекційному мононуклеозі достовірних змін концентрації цього імуноглобуліну не відзначили.

Додатково проаналізували показники імунограм у хворих на герпесвірусну інфекцію з використанням програми StatSoft Statistica 6.0. Встановили, що в контрольній групі, навіть при значеннях, що виходять за межі середніх величин, вміст ЦІК не перевищує 70 оптичних одиниць (рис. 3). Водночас у хворих на оперізувальний герпес та інфекційний мононуклеоз середній вміст ЦІК демонструє лише тенденцію до зростання на 25,67 \% та 40,80\% (P>0,05), а при інфекції, спричиненій HSV I або II типу, коливається у межах здорових осіб (рис. 3), що є свідченням ефективності гуморальної імунної відповіді при інфекційному мононуклеозі та при оперізувальному герпесі. 


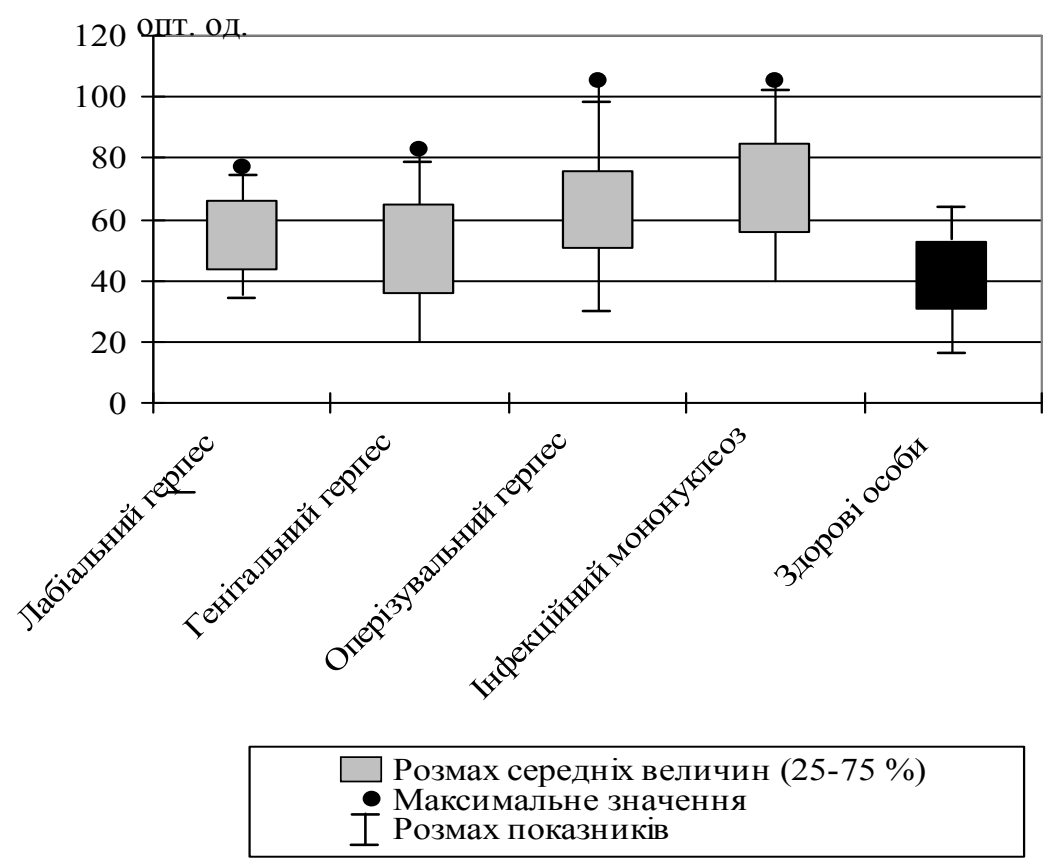

Рис. 3. Циркулюючі імунні комплекси у хворих на герпесвірусну інфекцію

Отримані нами дані частково узгоджуються 3 результатами, опублікованими іншими авторами $[5,6]$. Відомо, що герпетична інфекція рецидивує частіше і характеризується тяжчим перебігом в осіб з недостатністю функціонування імунної системи, а при вже розвинутій герпесвірусній інфекції спостерігаються не тільки набутий імунодефіцитний стан, але можливі й інші форми імунопатології - алергія або автоімунні процеси. Персистенція антигенів герпесвірусу може призводити до надмірного формування імунних комплексів, що мають різноманітний вплив на судинне русло багатьох органів і систем, формуючи імунокомплексну патологію. Герпесвіруси не тільки персистують, але й репродукуються в клітинах імунної системи, зумовлюючи загибель або зниження функціональної активності цих клітин, що сприяє тривалій персистенції. Таким чином, виникає своєрідне «порочне коло» $[5,7]$.

\section{Висновки}

1. У хворих на різні клінічні форми герпетичної інфекції формується тенденція до зниження більшості показників клітинного імунітету. Тільки при генітальному, оперізувальному герпесі та інфекційному мононуклеозі число $\mathrm{TCD}^{+}-$, $\mathrm{TCD} 4^{+}$-лімфоцитів достовірно знижується, а імунорегуляторний індекс знижується тільки при інфекційному мононуклеозі $(\mathrm{P}<0,05)$.

2. Концентрація у сироватці крові ІЛ-8, ІЛ10, ІЛ-12, ІЛ-17 та більшість показників гуморального імунітету не зазнає суттєвих змін. Разом 3 тим відзначається підвищення рівня сироваткового IgA при лабіальному герпесі та/або афтозному стоматиті, а також при генітальному герпесі.

Перспективи подальших досліджень. У подальшому планується вивчення впливу герпесвірусів на імунний статус ВІЛ-інфікованих пацієнтів, визначення ефективності базисної та комбінованої схем лікування.

\section{Література}

1. Герпес (этиология, диагностика, лечение) / И.Ф. Баринский, А.К. Шубладзе, А.А. Каспаров [и др.]. - М.: Медицина, 2006. - $272 \mathrm{c}$.

2. В. А. Исаков. Патогенез и лабораторная диагностика герпеса: Руководство для врачей / В.А. Исаков, В.В. Борисова, Д.В. Исаков. - СПб.: Лань, 2008. - 205 с.

3. Современная терапия герпесвирусных инфекций: Руководство для врачей / В.А. Исаков, С.А. Сельков, Л.К. Мошетова [та ін.]. - СПб.-М., 2004. - 167 с.

4. С.Н. Лапач. Статистические методы в медикобиологических исследованиях с использованием Ехcel / С.Н. Лапач, А.В. Чубенко, П.Н. Бабич. - К.: МОРИОН, 2000. $-320 \mathrm{c}$.

5. В.А. Исаков Противовирусная терапия герпеса у больных с иммунодефицитами / В.А. Исаков, М.М. Сафронова, Ю.В. Аспель // Terra medica. - 1999. - № 2. C. $12-14$.

6. Азовцева О.В. Клинико-патогенетическое и прогностическое значение изменений иммунного статуса и антиоксидантной системы у больных герпес- и ВИЧинфекцией: автореф. дисс. на соискание уч. ст. канд. мед. наук: 14.00 .10 - инфекционные болезни / О.В. Азовцева // - Великий Новгород, 2005. - 20 с.

7. Gartner B. EBV viral load detection in clinical virology / B. Gartner, J. K. Preiksaitis // J. Clin. Virol. - 2010. Vol. 48. - P. 8290.

\section{ВЛИЯНИЕ ГЕРПЕСВИРУСОВ НА ИММУННЫЙ СТАТУС ПАЦИЕНТОВ, НЕ ИНФИЦИРОВАННЫХ ВИЧ-ИНФЕКЦИЕЙ}

\section{М.А. Соколенко, В.Д. Москалюк, А. А. Соколенко}

Резюме. При анализе иммунограмм 59 больных с различными клиническими формами герпетической инфекции обнаружили тенденцию к снижению большинства показателей клеточного иммунитета. Только при гениталь- 
ном, опоясывающем герпесе и инфекционном мононуклеозе число TCD $3^{+}$-, TCD4 $4^{+}$-лимфоцитов достоверно снижалось, а иммунорегуляторный индекс испытывал статистически значимого снижения только при инфекционном мононуклеозе.

Концентрация сывороточных ИЛ-8, ИЛ-10, ИЛ-12 и ИЛ-17 и большинство показателей гуморального иммунитета испытывала существенные изменения. Вместе с тем, отметили повышение уровня IgA при лабиальном герпесе и/или афтозном стоматите, а также при генитальном герпесе.

Ключевые слова: герпетическая инфекция, клеточный и гуморальный иммунитет, цитокиновый статус.

\section{THE INFLUENCE OF HERPES VIRUSES ON IMMUNE STATUS OF PATIENTS NOT INFECTED WITH HIV}

\section{M.A. Sokolenko, V.D. Moskaliuk, A.A. Sokolenko}

Abstract. By analyzing immunogram of 59 patients with different clinical forms of herpes infection it has been established downward trend in most indicators of cellular immunity. The number of TCD3 ${ }^{+}-\mathrm{TCD}^{+}$-lymphocytes was significantly decreased in patients with genital, herpes zoster and infectious mononucleosis but the value of immunoregulatory index had a statistically significant reduction in patients with infectious mononucleosis only. In all analyzed forms of herpes infection the number of CD4-cells remains higher than the content of CD8-cells.

Serum levels of IL-8, IL-10, IL-12 and IL-17 and most indicators of humoral immunity did not undergo any significant changes. However, we noted the increasing levels of IgA in labial herpes and / or thrush, as well as genital herpes.

Key words: herpes infection, cellular and humoral immunity, cytokine status.

Higher State Educational Institution of Ukraine "Bukovinian State Medical University"

Рецензент - проф. І.Й. Сидорчук
Buk. Med. Herald. - 2016. - Vol. 20, № 1 (77). - P. 161-165

Надійшла до редакції 04.11.2015 року

(C) М.О. Соколенко, В.Д. Москалюк, А.А. Соколенко, 2016 